\title{
9. Internships and apprenticeships in Sweden, collective bargaining and social partner involvement
}

\author{
Jenny Julén Votinius and Mia Rönnmar
}

\subsection{INTRODUCTION}

The aim of this chapter is to explore forms of internships and apprenticeships within the Swedish labour law and industrial relations system and to discuss a number of current important problems and challenges. Specific attention is paid to collective bargaining and social partner involvement ${ }^{1}$ and the situation of young people, the traditional target group of internships and apprenticeships.

The definition of a young person varies with the policy context. In European Union (EU) policies on youth unemployment and labour-market statistics addressing young people, the category 'young people' covers people aged 15-24 years, and this definition is also used in most national legislation in the area, including in Sweden.

There is no established definition of the concepts of internship (also often referred to as traineeship) and apprenticeship. ${ }^{2}$ Both internships and apprenticeships contain an element of education or training for work. In apprenticeships the element of education is formal, whereas in internships the element of education can be vague and undetermined. It can also simply remain on paper, without being implemented. Moreover, whereas apprenticeships contain an element of 'work for payment', internships may or may not contain an element of paid work. If the internship is unpaid, the intern expects to get some reward other than pay. Such rewards can for instance be experience, contacts, a richer curriculum vitae (CV) or promises of future employment with the employer. Other unpaid internships operate in the sphere of volunteering, which also

\footnotetext{
1 In the Swedish context social partners are trade unions and employers' organizations.

2 Rosemary Owens and Andrew Stewart, 'Regulating for Decent Work Experience: Meeting the Challenge of the Rise of the Intern' (2016) 155 Int Lab Rev 679.
} 
includes altruistic and non-profit work driven by an ethical or ideological commitment.

In this chapter, the definitions of the concepts of internship and apprenticeship are specified to fit with the Swedish national context. People who are enrolled in the educational system normally are eligible for the public study allowance, which means that the employer does not pay a wage. In the Swedish context, the definition of apprenticeship as 'work for payment' should thus be modified to 'work for payment or work qualifying for the study allowance'. ${ }^{3}$

A legal-analytical method is applied in this chapter to clarify and systematize the content of the law. Furthermore, this chapter emphasizes collective bargaining and provides an integrated analysis of labour law and industrial relations. ${ }^{4}$ The chapter is structured as follows. Section 9.2 provides a discussion of the labour market situation of young people and different forms of internships and apprenticeships. Section 9.3 presents the labour law and industrial relations framework, and section 9.4 discusses collective bargaining and social partner involvement. Finally, section 9.5 comprises a concluding discussion.

\subsection{THE LABOUR MARKET SITUATION OF YOUNG PEOPLE AND DIFFERENT FORMS OF INTERNSHIPS AND APPRENTICESHIPS}

Prominent features of the Swedish labour market are high employment, high employment continuity over the life course and relatively low gender disparities in labour market integration. ${ }^{5}$ The number of employees in Sweden was just over 4.8 million people in November 2019. The employment rate is around 68.3 per cent of the total workforce, whereas the unemployment rate is 6.9 per cent of the total workforce. Slightly more men than women are unemployed. ${ }^{6}$

\footnotetext{
3 In Sweden the term 'trainee' normally refers to an employed person admitted to a high-profile company-designed programme to promote newly recruited people in the white-collar sector. Thus this term is not used in discussions of internships and apprenticeships.

4 The materials subjected to analysis are legal sources (eg legislation at national, EU and international levels; preparatory works to the legislation; collective agreements; and case law), policy documents, and legal and industrial relations scholarship.

5 Dominique Anxo, 'Towards an Active and Integrated Life Course Policy: The Swedish Experience' in Dominique Anxo, Gerhard Bosch and Jill Rubery (eds), The Welfare State and Life Transitions: A European Perspective (Edward Elgar 2010) 113.

6 Labour Force Surveys, November 2019. An unemployed person is here defined as someone who lacks employment, can and wants to take up work within 14 days, and has actively searched for jobs during the last month.
} 
Although the labour market is performing well, it faces significant challenges. There are serious difficulties with labour shortages and skills mismatches. The issue of mismatches between qualifications and labour-market requirements has often been highlighted in relation to low-skilled people. However, the issue of mismatches is also relevant for highly qualified people, in that their skills, although high, do not correspond well with what is desired in the labour market. ${ }^{7}$ The challenges related to competence provision constitute a problem both at the societal level and for individual employers. For many years now, this issue has drawn a great deal of attention and engagement from social partners.

A closely related important and more recent challenge in the labour market is the integration of non-EU migrants into the labour force. ${ }^{8}$ The increasing number of refugees and newly arrived immigrants presents new challenges that have to be handled within the labour market and collective bargaining context. In November 2019, unemployment rates for people born outside Sweden were 19.7 per cent, in comparison to 3.9 per cent for people born in Sweden. ${ }^{9}$ In general, it takes a long time for refugees and newly arrived immigrants to establish themselves in the Swedish labour market, which makes the labour market situation for this group even more challenging. ${ }^{10}$ The policy measures introduced to promote the labour market inclusion of newly arrived immigrants in Sweden include early skills assessment, the recognition of qualifications, language courses, vocational training, job training and general education for learners with low levels of education. In many EU countries, social partners play an active role in education and apprenticeships, accelerating labour market access and recruitment of refugees. ${ }^{11}$ Inclusion of these workers is fundamental not only to increase employment and growth, but also to

\footnotetext{
${ }^{7}$ European Commission, Moving Youth into Employment COM(2012) 727 final, 5.

8 The refugee situation has created an urgent societal need to advance the inclusion of newly arrived immigrants in the labour market. This is clearly the case in Sweden, where many people have sought and received refuge. In 2015, for example, 160000 people sought refuge in Sweden, and among them were 70000 children (half of whom were unaccompanied).

$9 \quad$ Swedish Public Employment Service, Arbetsförmedlingens verksamhetsstatistik november 2019 (Arbetsförmedlingen 2018), https://mb.cision.com/Public/1326/ 2986880/9f4bf8826b4242fd.pdf, accessed 30 March 2021.

10 Stefan Eriksson, Lena Hensvik and Oskar Nordström Skans, Den svenska arbetsmarknaden och dess utmaningar (IFAU 2017); Arbetsförmedlingen, Ungdomsarbetslösheten och ungdomsgarantin - en översikt (Arbetsförmedlingen 2017).

11 Filip Tanay and Jörg Peschner, Labour Market Integration of Refugees in the EU (European Commission 2017); Eurofound, Approaches to the Labour Market Integration of Refugees and Asylum Seekers (European Union 2016).
} 
achieve and maintain overall stability and legitimacy, in society in general and for the collective bargaining system. New demands have to be accommodated by the trade union movement, which at times has been reluctant to recognize gender inequality and the need for diversity perspectives. ${ }^{12}$

The labour market situation for young people ${ }^{13}$ is generally much better than it was only a few years ago. Since 2012, youth unemployment rates in Sweden have fallen considerably, although a slight rise can be seen since 2018. In November 2019, the youth unemployment rate was 19.8 per cent. ${ }^{14}$ Some groups of young people have a very weak position in the labour market: early school leavers, young people with reduced working capacity and young people born outside Europe. Around 15 per cent of Swedish employees are in fixed-term employment. Fixed-term employment is by far the most common among young people; in 2018, 50 per cent of employed women and 38 per cent of employed men in the age group 20-25 years had fixed-term employment. ${ }^{15}$ Considerably more women than men, and a large proportion of the young workforce, work part-time, around a quarter of them involuntarily. The most vulnerable young people in the labour market, that is, those not in education, employment or training (NEETS), were 8 per cent of the age group 15-24 years in 2018, in comparison to the EU average of 16.5 per cent. ${ }^{16}$ In parallel with the decline in youth unemployment, another group of unemployed people has quickly increased in numbers: newly arrived migrants or refugees, as described previously. These two groups overlap, as many of those who have recently migrated to Sweden are young. Currently, the Swedish labour market is marked by increasing segmentation between the majority of workers and groups of workers that have a particular difficulty in establishing themselves in the labour market, such as refugees and newly arrived immigrants, early school leavers and older unemployed people.

12 Yvonne Hirdman, Med kluven tunga: LO och genusordningen (Atlas 1998); Rianne Mahon, 'Sweden's LO: Learning to Embrace the Differences Within?' in Fiona Colgan and Sue Ledwith (eds), Gender, Diversity and Trade Unions: International Perspectives (Routledge 2002).

${ }_{13}$ This section partly builds on Julén Votinius's previous research: Jenny Julén Votinius, 'Youth, Labour Law, and European Economic Crisis' in Ulf Bernitz, Moa Mårtensson, Lars Oxelheim and Thomas Persson (eds), Bridging the Prosperity Gap in the EU: The Social Challenge Ahead (Edward Elgar 2018).

14 Labour Force Surveys, November 2019.

15 Akademikernas a-kassa, Arbetslöshetsrapporten (Akademikernas a-kassa 2019).

16 Eurostat, 'Statistics on Young People Neither in Employment nor in Education or Training' (Eurostat Statistics Explained, April 2019), https://ec.europa.eu/eurostat/ statistics-explained/index.php/Statistics_on_young_people_neither_in_employment _nor_in_education_or_training, accessed 30 March 2021. 
The Swedish educational system follows a structure of nine years of mandatory school, three or four years of secondary education, then higher education. In addition, to promote lifelong learning and to secure access to education in all stages of life, municipal adult education (Komvux), folk high schools (folkhögskola), and vocational training within labour market policies (yrkesinriktad arbetsmarknadsutbildning) are crucial. In order to promote labour market transition and to secure a supply of workers with adequate competences, the current government plans to expand and strengthen these systems for lifelong learning. ${ }^{17}$

Swedish labour market policy emphasizes active labour market programmes and vocational training, aiming to reduce benefit dependency and passive measures for the unemployed. ${ }^{18}$ Labour market measures are designed to prevent long unemployment periods and to integrate the unemployed into the labour force. Within general labour market policy, special programmes target particularly vulnerable groups, whereas other programmes are open to anyone registered at an employment office. The Swedish Public Employment Service (Arbetsförmedlingen), which up until now has been responsible for managing and monitoring the programmes, providing support for unemployment benefit recipients, and contributing in different ways to a well-functioning labour market, is currently subject to substantial reform and downsizing. Following political negotiations after the 2018 elections and the subsequent formation of the government in early 2019, a major part of the responsibilities of the Swedish Public Employment Service will be transferred to private companies. ${ }^{19}$ The detailed content and effects of these changes are yet to be seen but, given the extent of the reform, the implications will be significant.

We now briefly explore different forms of internships and apprenticeships in Sweden. Unpaid internships are less common than apprenticeships. The most typical group of unpaid interns are young people who in connection with their university studies spend a period abroad at the United Nations, non-government organizations or similar organizations to gain experience, seek adventure and enhance their prospects of future work. A different group of unpaid interns is found in the blue-collar sectors of retail and restaurants. Here, some employers may require young people to conduct a period of unpaid

17 These plans are part of the so-called 'January Agreement' (januariöverenskommelsen): see section 9.3 in this chapter.

18 Dominique Anxo and Thomas Ericson, Labour Market Measures in Sweden 2008-13: The Crisis and Beyond (ILO 2015).

19 Swedish Public Employment Service, Vissa förutsättningar inför reformeringen av Arbetsförmedlingen (Arbetsförmedlingen 2019), https://arbetsformedlingen .se/download/18.47a458fb16df81b9133207b/1572604962796/vissa-forutsattningar -reformeringen-arbetsformedlingen.pdf, accessed 30 March 2021. 
test work before, possibly, being offered employment. The extent of this practice is unknown, and it is strongly opposed by the trade unions.

Apprenticeships appear as part of the educational system and within labour market policies. Within the educational system, mandatory on-site training periods are part of a number of educational programmes, such as for teachers and medical doctors, and are optional for other educational programmes, such as for lawyers. These apprentices are eligible for the study allowance. Mandatory periods of on-site training are also part of some secondary-level educational programmes, not least within the construction sector. In some programmes, the young person counts as a school pupil and is eligible for the study allowance (yrkesprogram or arbetsplatsförlagt lärande). In other programmes, the young person is employed by the company providing the on-site training, and receives payment according to a collective agreement (gymnasielärling).

Within the framework of active labour market policies, several forms of subsidized employment have been available since the early 1980s. Subsidized employment may be combined with training or education, but that is not always a requirement. The subsidies aim to compensate employers in instances where the expected productivity of an employee is not high enough to bear contractual wage costs. ${ }^{20}$ The subsidy may cover the payroll tax, as for some of the new-start jobs (nystartsjobb) for people who for various reasons have been away from the labour market. In other instances, the subsidy covers 100 per cent of the wage costs; the labour market measure termed extra services (extratjänster) in the welfare, public, cultural or non-profit sectors is provided for very long-term unemployed and newly arrived migrants who work full-time and is paid according to a collective agreement. Since 2018, introduction jobs (introduktionsjobb) with 80 per cent compensation of the wage costs have replaced a number of other measures (but not the new-start jobs or the extra services). (These introduction jobs, a specific statutorily regulated labour market measure, are not to be confused with employment resulting from introduction agreements, discussed in section 9.4.) In addition to subsidized employment, individual plans for support in education, training and employment may be provided by the Swedish Public Employment Service. Currently, the measures provided within Swedish labour market policies are particularly difficult to assess and describe. As a consequence of the transformation of the Swedish Public Employment Service, labour market policies are in flux.

Measures introduced through collective bargaining and social partner involvement can be seen in the construction sector and in some other pro-

20 Anders Forslund, Subventionerade anställningar: Avvägningar och empirisk evidens (IFAU 2018). 
fessions (such as the glass industry), which provide a collectively bargained system for traditional apprenticeships, where the young person is employed as an apprentice without simultaneously being enrolled in an educational programme as a school pupil. The content and conditions of such apprenticeships are regulated in collective agreements. ${ }^{21}$ Two other, more recent, examples of actions initiated through collective bargaining and social partner involvement are introduction agreements and establishment employment, which is discussed in section 9.4.

\subsection{THE LABOUR LAW AND INDUSTRIAL RELATIONS FRAMEWORK}

Internships and apprenticeships raise a number of different issues related to the labour law and industrial relations framework (such as flexible work, age discrimination, and terms and conditions of employment). However, the focus of this section is on collective bargaining and social partner involvement, the notion of the employee and the scope of labour law protection.

The Swedish labour law and industrial relations system is based to a large extent on self-regulation through autonomous collective bargaining. Wages and employment conditions are generally set by collective agreements. Most Swedish labour legislation is semi-compelling, and allows for deviations by way of collective bargaining, whether to the advantage or detriment of individual workers. The relationship between trade unions and employers' organizations has traditionally been characterized by cooperation and social partnership. There is elaborate regulation of information, consultation and co-determination in the Co-determination Act (1976:580) (MBL) and complementary collective agreements. Worker participation is channelled through trade unions and their representatives, at local and central levels, in a single-channel system. Trade unions both negotiate and conclude collective agreements on wages and other working conditions, and take part in information and consultation at the workplace level.

A number of trends currently influence and challenge industrial relations and national collective bargaining systems in Europe and worldwide. ${ }^{22}$ A global trend towards individualization and decentralization has weakened

21 On the apprenticeship system in Sweden in a comparative European perspective, see Jonas Olofsson, Lärlingsutbildning: Svenska erfarenheter och initiativ $i$ ett europeiskt perspektiv (SIEPS 2014); National Mediation Office, Avtalsrörelsen och lönebildningen 2013: Medlingsinstitutets årsrapport (National Mediation Office 2014) 149ff.

22 See eg Susan Hayter (ed), 'What Future for Industrial Relations? Special Issue' (2015) 154(1) Int Lab Rev; OECD, OECD Employment Outlook 2016 (OECD 2016); 
trade unions and collective bargaining, and has resulted in a decrease in trade union organization rates and collective bargaining coverage. In Sweden, the trade union organization rate is still high at about 70 per cent (even though there has been a significant drop in the past ten years) and the employers' organization rate is about 90 per cent. There are, however, important differences between sectors and groups of employees. Thus, in the hospitality and retail sectors the trade unionization rates are significantly lower, and the same applies for young workers. The collective bargaining coverage is about 90 per cent. ${ }^{23}$ Since the 1990 s, there has been a clear tendency towards individualization and 'organized' decentralization of industrial relations and wage negotiations in Sweden. ${ }^{24}$ The stability of the Swedish collective bargaining system has been brought into question in recent years, and increasing tension and diversity characterizes the collective bargaining system, and its different sectors and levels. ${ }^{25}$

Important traditional functions of collective bargaining in Sweden include creating a peace obligation and social truce; regulating wages and employment conditions; adapting statutory regulation to sectoral or company circumstances; complementing the statutory social security system; ${ }^{26}$ protecting individual employees; regulating and facilitating negotiations and other collaboration between social partners; and supervising and enforcing employment conditions. ${ }^{27}$ More recently, promoting the labour market inclusion of specific groups, such as young workers, older workers and newly arrived immigrants, has surfaced as a function of collective bargaining.

Collective agreements in Sweden are entered into at different levels. Nationwide collective agreements are concluded at the sectoral level, and

European Commission, Industrial Relations in Europe 2014 (European Commission 2015).

23 Medlingsinstitutet, Avtalsrörelsen och lönebildningen 2018: Medlingsinstitutets årsrapport (Medlingsinstitutet 2019) $199 \mathrm{ff}$.

24 See eg Franz Traxler, 'Farewell to Labour Market Associations? Organized versus Disorganized Decentralization as a Map for Industrial Relations' in Colin Crouch and Franz Traxler (eds), Organized Industrial Relations in Europe: What Future? (Avebury 1995).

25 For a more developed discussion on the functions of, trends in and pressures on the Swedish autonomous collective bargaining system, see Mia Rönnmar, 'Autonomous Collective Bargaining in Sweden under Pressure' in Julia López López (ed), Collective Bargaining and Collective Action: Labour Agency and Governance in the 21st Century? (Hart 2019).

26 For example, through additional regulation of occupational pensions, unemployment benefits and parental leave benefits.

27 See eg Axel Adlercreutz, Kollektivavtalet: Studier över dess tillkomsthistoria (CWK Gleerup 1954); Folke Schmidt and others, Facklig arbetsrätt (Norstedts juridik 1997). 
supplemented by local collective agreements concluded at the workplace level. In addition, some master agreements are concluded at the national level. Currently, wages are mostly set through individual and local bargaining within a sometimes very general framework of national sectoral bargaining. The Swedish labour market is covered by about 670 national sectoral collective agreements.

A collective agreement is statutorily defined as 'an agreement in writing between an organization of employers or an employer and an organization of employees about conditions of employment or otherwise about the relationship between employers and employees' (MBL s 23). Within its area of application, a collective agreement is legally binding not only on the parties to the agreement but also on their members (MBL s 26). In addition, an employer bound by a collective agreement is obliged to apply it to all employees, regardless of trade union membership. A collective agreement has both a normative and mandatory effect (MBL s 27). Unless otherwise provided for by the collective agreement, employers and employees bound by the agreement may not deviate from it by way of an individual employment contract. Such a contract is null and void, and breaches of the collective agreement are sanctioned by economic and punitive damages. In most cases collective agreements set minimum standards only, allowing employers, trade unions and employees to agree on better terms and conditions of employment by way of a local collective agreement concluded at the workplace level, or an individual employment contract. ${ }^{28}$

There is no statutory minimum wage or system for extension of collective agreements. However, as we have seen, the collective bargaining coverage is about 90 per cent and a de facto erga omnes effect is achieved..$^{29}$ In line with the autonomous collective bargaining system, it is the role of social partners to safeguard a general level of pay and employment conditions. ${ }^{30}$ Supervision and enforcement of terms and conditions of employment are carried out to a large extent by the trade unions or social partners in cooperation. Thus, effective enforcement depends to a large degree on the workplace being covered by a collective agreement. ${ }^{31}$

28 See Jonas Malmberg, Anställningsavtalet: Om anställningsförhållandets individuella reglering (Iustus 1997) 144ff; Mikael Hansson, Kollektivavtalsrätten: En rättsvetenskaplig berättelse (Iustus 2010).

29 See Medlingsinstitutet (n 23).

30 The trade unions do this by trying to force employers who are not members of an employers' organization (and thereby not automatically bound by collective agreements) to conclude 'application agreements' (hängavtal). If agreement cannot be reached by way of negotiations, the trade unions have the right to take collective action.

31 Cf Niklas Bruun and Jonas Malmberg, 'Lex Laval - Collective Actions and Posted Work in Sweden' in Roger Blanpain and Frank Hendrickx (eds), Labour 
Labour law (especially employment protection and redundancy dismissal and seniority rules) and industrial relations are at the centre of the political and societal debate, and are addressed by the January Agreement (januariöverenskommelsen). The January Agreement was concluded at the beginning of 2019 (after general elections held in September 2018 and difficulties in forming a government) among four political parties forming the current government (the Social Democratic Party and the Green Party) and its parliamentary support (the Liberals and the Center Party). The January Agreement sets out 73 action points for the government's programme and collaboration between the political parties for the upcoming four-year period. The January Agreement also reflects a growing tension between collective bargaining and legislative intervention.

Swedish labour law and collective bargaining is characterized by a uniform and extensive personal scope, and a traditionally high degree of equal treatment of different categories of employees, such as blue- and white-collar employees and private- and public-sector employees.

The notion of employee (det civilrättsliga arbetstagarbegreppet) is not statutorily defined, but its content and meaning have been described and developed by the courts in case law and the legislature in preparatory works. ${ }^{32}$ In order to determine whether or not a specific person is an employee, the court makes an overall assessment of the situation, taking all relevant factors of the individual case into consideration. The multi-factor test applied by the courts focuses on the individual person in question, and on whether the overall situation of this person is similar to that of an ordinary employee or an ordinary self-employed worker. The courts take a number of factors into consideration, such as a personal duty to perform work according to the contract; the actual personal performance of work; whether there are any predetermined work tasks; a lasting relationship between the parties; whether the worker is subject to the orders and control of the principal or employer concerning the content, time and place of work; whether remuneration is paid, at least in part, as a guaranteed salary; and whether the economic and social situation of the

Law between Change and Tradition: Liber Amicorum Antoine Jacobs (Kluwer Law International 2011).

32 See further Mia Rönnmar, 'New Forms of Employment in Sweden' in Bernd Waas (ed), New Forms of Employment in Europe (Wolters Kluwer 2016). For a classical and comprehensive study of the notion of employee, see Axel Adlercreutz, Arbetstagarbegreppet: Om arbetstagarförhållandet och därtill hörande gränsdragningsfrågor i svensk civil - och socialrätt (PA Norstedts \& Söners Förlag 1964). The Co-determination Act (1976:580), regulating freedom of association, collective bargaining, collective action and information, consultation and co-determination, applies not only to employees, but also to the 'quasi-employee' category of jämställda uppdragstagare. 
worker is equal to that of an ordinary employee. ${ }^{33}$ The notion of employee is a mandatory concept. In order to prevent the parties to a contract from circumventing labour legislation and depriving the employee of protection, the courts are not bound by the description or definition of the relationship given by the parties themselves, for example, in a written contract. The court conducts an independent assessment of the legal nature of the relationship on the basis of the actual situation. However, the parties to the contract are, in principle, free to organize their relationship and the ways in which the work will be carried out, in practical terms. A court may then find that these practical arrangements, and the overall situation of the worker, best fit the description of a self-employed worker. ${ }^{34}$

There has been a trend towards a uniform and far-reaching notion of employee, and the extent of the notion of employee has continuously widened, aiming at providing additional groups of workers with the protection afforded by labour law and labour legislation. ${ }^{35}$ Many interns and apprentices are covered by the notion of employee, and fall within the scope of labour law protection. Those who are not employees may still be covered by some labour legislation, such as legislation on the working environment and non-discrimination.

\subsection{COLLECTIVE BARGAINING AND SOCIAL PARTNER INVOLVEMENT ${ }^{36}$}

Important reasons for the long-standing Swedish tradition of social partner involvement in efforts to meet labour market challenges are the need to secure

33 See Government Inquiry Report SOU 1975:1, 721ff; Government Inquiry Report SOU 1993:32, 216ff; Government Inquiry Report SOU 1994:141, 74ff; Government Inquiry Report Ds 2002:56. See also eg Labour Court judgments AD 2013:92 and AD 2013:32.

34 The Labour Court is sensitive to attempts to circumvent labour legislation, and will frequently rule in favour of an employment relationship if the person in question has gone from being an employee of the employer to an alleged self-employed worker.

35 In recent years, there has been a growth in so-named egenanställningsföretag (sometimes referred to as umbrella companies, portage salarial or professional employer organizations), where a (basically) self-employed person offering their services is employed by such a company, and the company, in return for a fee, pays wages, social security contributions and taxes, and deals with invoices and other administrative work.

36 This section draws upon earlier research by Rönnmar in the area of intergenerational bargaining, age discrimination and collective bargaining. See Mia Rönnmar, Intergenerational Bargaining: Sweden (iNGenBar 2014); Mia Rönnmar, 'Does Age Matter? Sweden, Younger and Older Workers and the Intergenerational Dimension of Contingent Work' in Edoardo Ales, Olaf Deinert and Jeff Kenner (eds), Core and Contingent Work in the European Union: A Comparative Analysis (Hart 2017); 
the transition of skills and knowledge between generations of employees, and to secure a supply of competent workers. As early as 1938, in connection with the conclusion of the historic Saltsjöbaden Agreement, social partners decided to regulate apprenticeships in sectoral collective agreements. ${ }^{37}$

Trade unions are very attentive to individual employers' practices that take advantage of unemployed people by offering them unattractive positions that involve a risk of exploitation. In the large parts of the labour market that are covered by collective agreements, unpaid or low-paid test work and similar arrangements are likely to constitute an infringement of the collective agreement. In companies that are not covered by collective agreements, which is particularly common in small retail companies and restaurants, it is difficult for the trade union to act against the employer. Here, instead, the strategy of the trade unions has been to encourage job applicants - particularly young people - to reject unpaid test periods, thus limiting the supply of potential employees for this type of practice. The Swedish Trade Union Federation (LO) provides an on-call service for young people, which every summer is promoted in public relations campaigns in media and through other outreach work.

The urgent demand for skilled and competent employees is a strong driving force for employers, but also for trade unions, to find joint solutions in collective bargaining. In the following, two examples of measures in this area initiated through collective bargaining and social partner involvement are discussed: introduction agreements and establishment employment.

Introduction agreements for young workers (yrkesintroduktionsavtal) are one example of apprenticeships introduced in recent years. Youth unemployment and the desire for labour market inclusion of young workers form the background to these national sectoral collective agreements. Introduction agreements regulate employment for young workers, combining work with education, training and supervision.

In 2010, the employers' organization Teknikföretagen and the trade union IF Metall concluded a pioneer introduction agreement in the industrial sector, and introduction agreements have since been concluded in several other sectors, such as in the municipal/regional health-care and care sector, the retail sector, and the wood and graphic design sectors. ${ }^{38}$

Mia Rönnmar, 'Age Discrimination and Labour Law: A Comparative Analysis' in Ann Numhauser-Henning and Mia Rönnmar (eds), Age Discrimination and Labour Law: Comparative and Conceptual Perspectives in the EU and Beyond (Kluwer Law International 2015); Rönnmar, 'Autonomous Collective Bargaining' (n 25).

37 Jonas Olofsson, Svensk yrkesutbildning: Vägval i internationell belysning (SNS Förlag 2005).

38 See Arbetsförmedlingen, Aterrapportering 2014, Yrkesintroduktionsanställningar, 1 augusti 2014 (Arbetsförmedlingen 2014); see also Regeringen, Yrkesintroduktionsanställningar - en ny väg till jobb för unga (Regeringen 2014). 
In 2012, the government started negotiations with social partners on a tripartite job pact, aimed at tackling youth unemployment. One of the aims was to provide young people with employment through introduction agreements, partly financed by the state. The Confederation of Swedish Enterprise (Svenskt Näringsliv) later withdrew from the negotiations, but negotiations on further introduction agreements continued at the national sectoral level between the social partners. In 2013, the government presented a number of proposals emanating from these and other tripartite consultations, aimed at improving the functioning of the labour market and creating higher employment and lower unemployment through action in three areas: introduction agreements, transition and employability, and short-term working arrangements in times of severe economic crisis. ${ }^{39}$ In 2014, a government regulation entered into force establishing a government scheme to support and subsidize introduction employment for young workers. ${ }^{40}$ According to the scheme, an employer who hires a young person within the framework of a collectively bargained introduction agreement can be awarded financial support corresponding to ordinary employers' social security contributions and a monthly supervisor grant.

The original introduction agreement concluded by Teknikföretagen and IF Metall declared that the industry was facing a large generational renewal in the coming years, which had increased the need for new employees. Currently, work entails greater requirements for theoretical education and professional experience. Recruitment measures are, therefore, vital to secure the future long-term competence provision of industry. The aim of the introduction agreement was to stimulate companies in the industrial sector to offer introduction employment to young people so they could work and develop in their professional life in the Swedish labour market.

Introduction employment is aimed at young people under the age of 25 who lack relevant professional experience. The introduction employment contract is a fixed-term contract, which may last for 12 months, with the possibility of an extension for up to an additional 12 months. Every introduction employment period is combined with supervision and an individual training plan regarding work tasks and educational and introductory elements. Wages paid are of at least 75 per cent of the collectively bargained minimum wage. The employer and the employee are free to terminate the introduction employment contract with one month's notice. If there is no termination, the introduction employment contract is converted into a permanent employment contract.

39 See Government Inquiry Report Ds 2013:20.

40 The government scheme has been authorized by the European Commission under EU state aid rules: see decision C(2013) 4053 final. See also Government Inquiry Report Ds 2013:20; Förordning (2013:1157) om stöd för yrkesintroduktionsanställningar. 
A common theme in interviews held with social partners for a research project on intergenerational bargaining was that introduction agreements are not seen as a labour market measure that can grow quickly into large volumes. Introduction agreements are only one way of combating youth unemployment and promoting young workers' entry into the labour market. Another important aim of collective agreements is to ensure provision of current and future competence. Introduction agreements are about securing a future core group of employees and building up competence. ${ }^{41}$

Introduction agreements in municipal and regional areas do not clearly address young workers or reserve introduction employment for them. Subsequently, the scope of introduction agreements - and the government scheme - has been extended to long-term unemployed people and newly arrived immigrants. ${ }^{42}$

Social partners have contributed to the creation of a fast track into the labour market for newly arrived immigrants. In February 2019 there were 14 different fast tracks, covering about 30 different professions. The fast tracks aim to secure skills provision in professions and sectors marked by skills and labour shortage, and to reduce the time newly arrived immigrants spend unemployed. The fast tracks are developed and run in collaboration among social partners, the Swedish Public Employment Service, and other authorities and actors. They cover a range of different measures, such as validation and recognition of qualifications, vocational training, job training and language courses. ${ }^{43}$

${ }^{41}$ Research on introduction agreements (and collective agreements on partial retirement, transition and redundancy) and intergenerational bargaining reveals that Swedish labour law, industrial relations and collective bargaining lack a clear intergenerational dimension, as well as an articulated debate on intergenerational solidarity or conflict. The interests of younger and older workers, and the labour market inclusion of these groups, are to a large degree dealt with separately and in parallel. The strategies to combat youth unemployment and to promote active ageing and a prolonged working life for older workers, respectively, are in principle seen as separate, equally important and non-conflicting strategies. Although Swedish collective bargaining developments display a lack of direct and explicit intergenerational bargaining, several indirect and implicit intergenerational elements can be found in collective agreements. These indirect intergenerational elements relate, for example, to generational renewal of future skills provision, competence development and transfer of knowledge and experience between older and younger workers, and older workers' participation in education and supervision of younger workers, as a way of adapting the working environment to enable a longer working life. See further Rönnmar, Intergenerational Bargaining (n 36).

42 See Government Bill prop 2016/17:100. See also Government Inquiry Report SOU 2018:81.

43 See Arbetsförmedlingen, Arbetsförmedlingens nulägesbedömning av arbetet med snabbspår: Juni 2018 (Arbetsförmedlingen 2018); Arbetsförmedlingen, 
Furthermore, as we touched upon previously, the scope of existing introduction agreements has been extended to include newly arrived immigrants. This is, for example, the case with the introduction agreement concluded between Teknikföretagen and IF Metall in the industrial sector.

The debate has also revolved around the creation of 'simple jobs' and the use of lower wages for newly arrived immigrants and other groups of workers. In this context, in August 2017 the Alliansen, the four centre-right political parties forming the political opposition at the time, presented a proposal for a new form of statutorily regulated form of employment, entry employment (inträdesjobb), for newly arrived immigrants and some categories of young workers. Controversially, and at odds with the Swedish autonomous collective bargaining system, this proposal built on statutorily regulated wages of no more than 70 per cent of the collectively bargained starting wage in the relevant sector. ${ }^{44}$

In November 2017 - partly as a reaction to the proposal regarding entry employment - a number of key social partners, such as the LO, Unionen ${ }^{45}$ and the Confederation of Swedish Enterprise, agreed, in principle, to conclude collective agreements on a new form of employment: establishment employment (etableringsjobb). Establishment employment is another recent example of apprenticeships.

In developing this agreement, they built on, and sought to improve upon, introduction agreements. The aim of the collective agreements and establishment employment is to help newly arrived immigrants and the long-term unemployed to become established in the labour market, and to facilitate future skills provision for employers. In March 2018, the social-democratic-green government and their social partners signed a declaration of intent whereby the government agreed to financially and otherwise support this initiative. The intention is to ensure that newly arrived immigrants and the long-term unemployed have opportunities to acquire knowledge and experience that are sought after in the labour market. Establishment employment will be open for newly arrived immigrants who have been granted residence in Sweden in the past 36 months, and for people with more than 12 months of unemployment (or six months of unemployment for those below 25 years of age). An employment contract under the scheme should lead to a permanent, full-time employment

Arbetsförmedlingens nulägesbedömning av arbetet med snabbspår: Februari 2019 (Arbetsförmedlingen 2019).

44 Up to a maximum of around SEK21 000 per month. During the period of employment, which could last for a maximum of three years, the employer would not have to pay payroll tax for the employed person. See further Alliansen, Inträdesjobb för fler $i$ arbete (Alliansen 2017).

45 Sweden's largest white-collar trade union in the private labour market. 
contract with the employer. The employee will be given the opportunity to take part in a language course and other short training courses as agreed by the employer and the employee. ${ }^{46}$

In 2018, the government asked the Swedish Public Employment Service to review and propose a new model for involving private actors in the matching related to establishment employment. ${ }^{47}$ Furthermore, the January Agreement, which is now to be implemented in different ways, addresses establishment employment and the labour market situation of newly arrived immigrants. It states that establishment employment, with lower wages, for newly arrived immigrants and the long-term unemployed is to be introduced (in line with the proposal of the social partners). Establishment employment will also be extended to companies without collective agreements and to temporary work agencies in a way that does not restrict the advantages of establishment employment. Measures shall be introduced to enable newly arrived immigrants to speed up the processes of labour market inclusion. In the spring of 2020 a government bill was approved, introducing some necessary adaptations to social security and tax regulation. ${ }^{48}$

\subsection{CONCLUDING REMARKS}

In Sweden, internships and apprenticeships are shaped within a labour law and industrial relations system that is strongly characterized by comprehensive social partner engagement and robust, innovative and constructive collective bargaining.

In the area of promoting lifelong learning and securing competence provision, collectively bargained solutions for internships and apprenticeships

46 See further Declaration of Intent of 5 March 2018 between the government, the LO, Unionen and the Confederation of Swedish Enterprise, https://www.government .se/49381d/contentassets/ae057fea761949e6950ad9a56dc81350/declaration-of-intent -between-the-government-the-swedish-trade-union-confederatio-lo-unionen-and-the -confederation-of-swedish-enterprise.pdf, accessed 3 March 2021. Cf the previous proposal along similar lines presented by the LO, LOs förslag om utbildningsjobb för stärkt etablering (LO 2017). In 2019, an employer's total payroll expenses for a position of this kind will amount to SEK8400 per month. In addition, the employee will receive a tax-free, individual state benefit amounting to at most SEK9870 per month in 2019. The government and the social partners agree that the salary and the individual benefit will follow wage developments. The individual state benefit can be claimed for no more than two years. The basic premise is that the size of the individual benefit should provide an incentive for the individual to obtain regular employment. The scheme must be brought in line with EU state aid rules, which might involve a notification to the European Commission.

47 See Regeringsbeslut 2018-05-31, A2018/01212/A.

48 See Government Bill Prop 2019/20:117; Government Inquiry Report Ds 2019:13. 
highlight key priorities and current important challenges for social partners and for the labour market. This is reflected in the two examples discussed in this chapter. Introduction agreements and establishment employment have been established and advanced in line with general developments in the labour market. As the labour market situation of young people has improved, the focus has partly shifted from young people to newly arrived migrants and the long-term unemployed.

Internships and apprenticeships typically raise a number of important problems and challenges. At the individual level, there is a risk of exploitation, for example, as regards unpaid interns or test work. Since there is no reliable information on the frequency of these practices in Sweden, it is difficult to assess the urgency of this risk, but the prevalence appears to be limited. Trade unions actively monitor developments in this area, and take preventive measures. At a collective or societal level, other challenges appear. First, internships and apprenticeships may exert downward pressure on wages generally, which affects other employees. In the Swedish debate, much attention has been directed towards the risks of wage dumping, and the crowding out of ordinary employment, that comes with labour market policy measures involving subsidized internships and apprenticeships. ${ }^{49}$ In a setting where unpaid or low-paid work becomes an important way to enter certain professions, other risks appear. Not everyone can afford to take up these positions; and there is a risk of reduced social mobility, increased socio-economic inequality and, in the long run, erosion of social legitimacy and cohesion. ${ }^{50}$ Again, in Sweden, there is nothing to indicate the frequent occurrence of unpaid or low-paid work in high-status professions. On the contrary, within several of these professions, the educational system provides mandatory optional periods of apprenticeship under which apprentices are eligible for the study allowance. An important challenge that is inherent in every form of apprenticeship is risks related to the balance between work and education; that the educational part is not comprehensive enough or is of low quality, and that there is little or no follow-up of the educational outcome. This potential problem is constantly present in the debate on internships and apprenticeships, in Sweden as in other countries. ${ }^{51}$

\footnotetext{
Forslund (n 20).

50 Cf Owens and Stewart (n 2), who also raise the risk that internships and apprenticeships may legitimize a downsizing of the education system. As a large part of the education is provided in the workplace, parts of the costs of education are passed on to young people in the form of unpaid or low-paid work.

51 European Commission, Apprenticeship Supply in the Member States of the European Union (Directorate-General for Employment, Social Affairs and Inclusion 2012).
} 
A final challenge that should be addressed in the Swedish context of internships and apprenticeships is the preservation of the labour market model and the role of social partners. Both introduction agreements and establishment employment follow a strong tradition of collectively bargained solutions where social partners have agreed upon the form and application of the reform, while the state's participation is limited to providing a financial contribution. However, in the course of implementing these solutions, the proposals put forward from the political right have followed a different path. This is articulated most clearly in the 2017 proposal for newly arrived immigrants and some categories of young workers, suggesting the introduction, for these categories, of statutorily regulated wages much lower than the collectively bargained starting wage. This proposal seriously challenges a number of cornerstones of the Swedish model, namely, that the autonomy of social partners should be left untouched, that wages are to be determined through collective bargaining and that the costs of labour market inclusion should be borne by the state. 